\title{
THE CHEMICAL COMPOSITION OF THE MEDIEVAL MIRRORS FROM GOLDEN HORDE TIME SETTLEMENTS ${ }^{1}$
}

\author{
Kseniya S. Kovaleva \\ Institute of Archaeology, RAS, Moscow, Russian Federation; \\ Volgograd State University, Volgograd, Russian Federation
}

\begin{abstract}
Introduction. The paper discussed the results of the study concerning the chemical composition of 16 mirrors from the Golden Horde period originating from the settlements Selitrennoe, Vodyanskoe, Uvekskoe Khmelevskoe I, Shirokiy Buerak and stored in the State Historical Museum (Moscow) and Saratov Regional Museum of Local Lore (Saratov). Method. The visual inspection of the items was carried out using the traceology method, XRF and SEM/EDS were used as a method of determining the elemental composition. To compare the results, data on the chemical composition of mirrors originating from other medieval sites in Eastern Europe were used. Analysis and Results. All but one mirror, made with a stone casting mold, were cast using the impression method. Some of the mirrors show traces of post-casting processing. Several types of alloys have been identified. Most of the mirrors were made of tin-lead bronze ( 7 items) with an increased (more than $20 \%$ ) tin content, which correlates with the results obtained on samples from other settlements of the pre-Horde and Horde times. Other large groups are mirrors made from multicomponent ( 3 items) and tin bronze (4 items). One mirror each is made of tin brass and lead bronze with the addition of arsenic. Mirrors with arsenic in their composition are also known from other samples from a nomadic cemetery of the Golden Horde period and settlement monuments, which indicates a sufficiently active existence of a more archaic metal in the $14^{\text {th }}$ century.

Key words: metal mirrors, medieval metalworking, Golden Horde, chemical composition, XRF analyzes, scanning electron microscopy.

Citation. Kovaleva K.S. The Chemical Composition of the Medieval Mirrors from Golden Horde Time Settlements. Vestnik Volgogradskogo gosudarstvennogo universiteta. Seriya 4. Istoriya. Regionovedenie. Mezhdunarodnye otnosheniya [Science Journal of Volgograd State University. History. Area Studies. International Relations], 2021, vol. 26, no. 5, pp. 17-29. (in Russian). DOI: https://doi.org/10.15688/jvolsu4.2021.5.2
\end{abstract}

\section{ХИМИЧЕСКИЙ СОСТАВ МЕТАЛЛА СРЕДНЕВЕКОВЫХ ЗЕРКАЛ ИЗ РАСКОПОК ПАМЯТНИКОВ ЗОЛОТООРДЫНСКОГО ВРЕМЕНИ ${ }^{1}$}

\author{
Ксения Сергеевна Ковалева \\ Институт археологии РАН, г. Москва, Российская Федерация; \\ Волгоградский государственный университет, г. Волгоград, Российская Федерация
}

\footnotetext{
Аннотация. Введение. В статье обсуждаются результаты исследования химического состава 16 зеркал золотоордынского времени, происходящих с городищ Селитренное, Водянское, Увекское и селищ Хмелевское I и Широкий Буерак и хранящихся в фондах Государственного исторического музея и Саратовского областного музея краеведения. Метод. Визуальный осмотр вещей проведен с помощью метода трасологии, исследование химического состава выполнялось неразрушающими методами, такими как рентгенофлюоресцентный анализ и сканирующая электронная микроскопия. Для сравнения результатов привлечены данные по химическому составу зеркал, происходящих из других средневековых памятников Восточной Европы. Анализ и результаты. Все, кроме одного зеркала, изготовленного при помощи каменной литейной формы, были отлиты по методу оттиска. На части зеркал присутствуют следы послелитейной обработки. Было выяв-
} 


\section{АРХЕОЛОГИЯ ЕВРАЗИЙСКИХ СТЕПЕЙ}

лено несколько типов сплавов. Большая часть зеркал изготовлена из оловянно-свинцовой бронзы (7 экз.) с повышенным (более 20 \%) содержанием олова, что соотносится с результатами, полученными на выборках из других поселений доордынского и ордынского времени. Другими большими группами являются зеркала из многокомпонентной (3 экз.) и оловянной бронзы (4 экз.). По одному зеркалу изготовлено из оловянной латуни и свинцовой бронзы с добавлением мышьяка. Зеркала с мышьяком в составе известны и по другим выборкам из кочевнического могильника золотоордынского времени и поселенческих памятников, что свидетельствует о достаточно активном бытовании в XIV в. более архаичного металла.

Ключевые слова: металлические зеркала, средневековая металлообработка, Золотая Орда, химический состав, рентгенофлюоресцентный анализ, сканирующая электронная микроскопия.

Цитирование. Ковалева К. С. Химический состав металла средневековых зеркал из раскопок памятников золотоордынского времени // Вестник Волгоградского государственного университета. Серия 4, История. Регионоведение. Международные отношения. - 2021. - Т. 26, № 5. - С. 17-29. - DOI: https://doi.org/ 10.15688/jvolsu4.2021.5.2

Металлические зеркала представляют собой яркую и информативную категорию материальной культуры древнего и средневекового мира. Многие из них обладают не только определенными физическими характеристиками (форма, размер, технология изготовления, химический состав), но и яркими иконографическими особенностями, и именно благодаря этому зеркала привлекали и привлекают до сих пор огромное внимание со стороны исследователей. Золотоордынским зеркалам, которые считаются практически массовым материалом, посвящен огромный пласт исследований. Прежде всего это работы по типологизации на основе особенностей их оформления Г.А. ФедороваДавыдова, Г.Ф. Поляковой, Л.Ф. Недашковского, К.А. Руденко [13, с. 48-67; 20, с. $223-$ $239 ; 22 ; 27$, c. 76-84].

Часто зеркала являлись предметом импорта, и вопрос происхождения как самих зеркал, так и изображений на них также поднимался среди исследователей. К.А. Руденко выделяет образы, используемые в оформлении зеркал, по происхождению на китайские и чжурчженьские, юго-восточные (мусульманские), южные и юго-западные (кочевнические алано-половецкие) и поволжско-золотоордынские [23, с. 151]. Зеркала всех этих групп могли быть как изготовлены на территории нижневолжских городов Золотой Орды (о производстве свидетельствуют относительно частые находки литейных форм и их фрагментов [28, с. 185,202$])$, так и быть предметами импорта. Решение вопроса по выявлению местных и привозных зеркал предполагается получить на основе статистически значимых серий анализов состава металла и выявления рецептур, характерных для разных регионов. На данный момент такая база данных по составу металла формируется для золотоордынского материала, где зеркала достаточно часто, благодаря своей массовости, попадают в выборку анализируемых изделий $[3 ; 4 ; 7 ; 10 ; 11 ; 17 ; 18 ; 30]$. Активно исследуются средневековые металлические зеркала Южной Сибири, где собрана представительная серия анализов $[2 ; 25$, с. $61-$ $88 ; 26$, с. 132], которая дает представление об алтайском и китайском металле.

В настоящей статье рассматриваются новые результаты исследования химического состава серии зеркал эпохи Золотой Орды ${ }^{2}$. Всего было изучено 16 фрагментов (табл. 1). Все они происходят с городов и поселений нижневолжского региона из слоев второй половины XIII - XIV в.: 7 экз. с Селитренного городища (с. Селитренное, Астраханская область), 2 экз. - с Водянского (окраина г. Дубовка, Волгоградская область), эта выборка получена в результате полевых исследований золотоордынских городищ Поволжской археологической экспедицией под руководством Г.А. Федорова-Давыдова в 1970-1990-х годах ${ }^{3}$. Еще 7 зеркал происходят из сборов разных лет на Увекском городище (окраина г. Саратов) и селищ его округи Хмелевское I и Широкий Буерак ${ }^{4}$ [14-16]. Часть полученных данных уже была опубликована [10, с. 334-343], часть вводится в научный оборот впервые.

Предварительный визуальный осмотр вещей проведен по установленной методике [5] с использованием стереомикроскопа Stemi 2000C (Zeiss) с камерой AxioCam ERc 5 s и цифрового микроскопа DigiMicro 2.0. Bce исследуемые зеркала представлены неболь- 
шими фрагментами, поэтому вопросы соотношения типов зеркал и состава металла, из которого они изготовлены, в данной статье не затрагиваются. На материале зеркал саратовского Поволжья Л.Ф. Недашковским было сделано наблюдение, что экземпляры с различной формой бортика имеют практически идентичный состав [18, с. 246].

Большинство (15 экз.) зеркал изготовлены методом литья по оттиску, когда литейная форма получается в результате оттиска зеркала-образца в сырой глине. Зачастую этот процесс мог циклично повторяться множество раз, и такие зеркала характеризуются нечетким, расплывчатым орнаментом. Одно из зеркал, происходящих из Селитренного городища (табл. 1,2), могло быть отлито в каменную литейную форму, либо быть изготовлено также по оттиску, но быть репликой первого порядка (рис. 1,1). На двух зеркалах зафиксированы следы доработки бортиков зубильцем (табл. 1,3,5, рис. 1,2), еще два зеркала (табл. $1,4,8$ ) имеют пробитые отверстия (рис. 1,3). Для достижения зеркального эффекта зеркала проходили полировку.

Исследование химического состава цветного металла предметов выполнялось двумя методами исследования. Анализ зеркал с Водянского и Селитренного городища проводился методом неразрушающего безэталонного рентгено-флуоресцентного анализа (РФА) на спектрометре M1 Mistral на базе отдела археологических памятников Государственного исторического музея ${ }^{5}$. Для зеркал Увекского городища и селищ Хмелевское I и Широкий Буерак проводился отбор проб размером 3-5 мм кв., которые исследовались методом сканирующей электронной микроскопии (SEM/EDS) на электронном сканирующем микроскопе Tescan VEGA3 с детектором EDS Oxford Instruments ${ }^{6}$. Ранжирование металлов и сплавов выполнено на основе методики, где пороговое значение для определения искусственных лигатур традиционно определено от $1,0 \%[6$, c. 131$]$.

Аналитическая часть. Проведенное внутри исследованной выборки ранжирование по заранее заданным параметрам позволило определить основные типы металлов и сплавов, использовавшиеся для изготовления золотоордынских зеркал.
Оловянная бронза (CuSn, $50 \leq \mathrm{Cu} \leq 99$, $1 \leq S n \leq 50)$.

Зеркала из оловянной бронзы представлены 4 экземплярами с Селитренного и Водянского городищ (табл. 1,6, 7,8,9). Содержание меди и олова в них колеблется в достаточно узких диапазонах $71,6-76,1$ и 23,0 26,9 \% соответственно. Такое четкое соблюдение пропорций позволяет сделать осторожное предположение о существовании определенной рецептуры.

Оловянно-свиниовая бронза (CuSnPb, $50 \leq C u \leq 98,1 \leq S n \leq 49,1 \leq P b \leq 49)$.

Самую большую группу в выборке - 7 экземпляров - составляют зеркала из оловянносвинцовой бронзы (табл. 1,2,13,14, 15, 16,17,18). Большая часть относится к высокооловянным бронзам с содержанием олова выше $20 \%$. Концентрация меди в выборке в целом составляет от 53,3 до 94,3\% (в среднем 72,8 \%), олова - от 7,6 до 44,4 \% (в среднем $24,6 \%$ ), а свинца - от 2,3 до $8,9 \%$ (в среднем $4,8 \%$ ). Все они (за исключением одного экземпляра из Селитренного городища) происходят из одного региона - Увекского городища и селищ его округи. Л.Ф. Недашковским исследована коллекция зеркал Увекского городища и селищ его округи, хранящихся в Национальном музее РТ, где также прослеживается преобладание оловянно-свинцовых бронз $[18$, c. 246$]$.

Именно оловянно-свинцовая бронза является классическим сплавом для изготовления китайских орнаментированных зеркал. Но рецептура, включающая в себя высокую долю олова (20-25\%) и свинца (10-15\%), и иногда с примесью мышьяка (ок. 1 \%), характерна для зеркал, изготовленных в Китае в VI-Х вв. н. э., уже в $\mathrm{X}$ в. из состава полностью исчезает мышьяк и значительно снижается концентрация основных элементов ( $\mathrm{Sn} 3-9$ \%, $\mathrm{Pb}$ 8$10 \%)$. К XIV в. концентрация свинца (10$14 \%)$ и олова (9-10\%) несколько возрастает [2, с. 140-141]. Особым индикатором китайских сплавов также является наличие индия (In) [2, с. 141], однако, как справедливо отмечается исследователями, методом РФА наличие этой микропримеси определить невозможно [26, с. 132].

По мнению Л.Ф. Недашковского, высокие концентрации олова в оловянно-свинцовых 


\section{АРХЕОЛОГИЯ ЕВРАЗИЙСКИХ СТЕПЕЙ}

бронзах средневековых зеркал характерны именно для производства, которое сложилось в золотоордынском Поволжье [18, с. 246]. Но такие рецептуры были распространены на территории Восточной Европы и раньше [24, c. 278], в том числе для отливки зеркал [21, c. 159]. Зеркала из оловянно-свинцовой бронзы с повышенным содержанием олова в золотоордынское время известны и за пределами нижневолжского региона, а также известны на Торецком селище, торгово-ремесленном поселении XV в. близ Биляра [4, с. 285; 7, табл., 260,264,322] и в материалах Болгарского городища [30, с. 272-273, табл. II, 18,20 24,26, III, 18-20]. Среди древнерусских вещей известно зеркало из сборов на селищах Устье 2 и Устье 3 (Тульская область (XII - третья четверть XV в.), которое также демонстрирует близкий, но все же отличающийся по пропорциям состав $(\mathrm{Cu}-49,4 \%, \mathrm{Sn}-44,7 \%, \mathrm{~Pb}-$ $5,1 \%)$ [6, с. 178 , № 1297]. Среди вятеческих материалов середины XII - XIII в. также присутствует зеркало из Серенска, характерное для кочевников южнорусских степей, изготовленное из свинцово-оловянной бронзы, где процент олова составляет $19,1 \%$ [8, с. 262 , 304, № 94].

Оловянная латунь (CuZnSn, $50 \leq \mathrm{Cu} \leq 98$, $1 \leq S n \leq 25,1 \leq Z n \leq 30, Z n \geq S n)$.

Из оловянной латуни в изученной выборке изготовлено одно зеркало из Селитренного городища (табл. 1,1 ), металлы определены в следующих концентрациях: $\mathrm{Cu}-74,7 \%, \mathrm{Zn}-$ $17,7 \%, \mathrm{Sn}-7,3 \%$

Свиниовая бронза (CuPb, $50 \leq \mathrm{Cu} \leq 99$, $1 \leq P b \leq 50)$ с добавлением мышияяка (As).

Из свинцово-мышьяковистой бронзы изготовлено также одно зеркало, происходящее из Селитренного городища (табл. 1,3), процент меди в нем составляет 93,1\%, свинца $-2,5 \%$, мышьяка $-3,2 \%$. Такой состав предположительно является либо свидетельством раннего происхождения самого зеркала, либо следствием переплавки других, более архаичных изделий. Мышьяковистые бронзы активно использовались в эпоху раннего железного века на Алтае и Кавказе [1, с. $65 ; 25$, с. 86]. Среди материалов эпохи Золотой Орды также известны и другие зеркала из бронз с мышьяком. Из Бахтияровского III могильника, некрополя близ Царевского городища конца
XIII - XIV в., оставленного кочевым населением Улуса Джучи [31, с. 86], происходит зеркало из многокомпонентного сплава с мышьяком и сурьмой в составе $(\mathrm{Cu}-47,7 \%, \mathrm{Sn}-$ $42,6 \%, \mathrm{~Pb}-5,5 \%, \mathrm{Zn}-1,4 \%$, As - 1, $1 \%, \mathrm{Sb}-$ $1,1 \%)$ [11, табл. 1,11$]$, типологически также относящееся к древностям кочевников XIIIXIV вв. (тип B-I-7 по Г.Ф. Поляковой [20, c. 224]). Еще два зеркала с добавлением мышьяка $(\mathrm{Cu}$ - основа, $\mathrm{Sn}-6,92 \%, \mathrm{~Pb}-16,1 \%$, $\mathrm{Zn}-1,0 \%$, As - 1,1\%) и мышьяка и сурьмы $(\mathrm{Cu}-$ основа, $\mathrm{Sn}-21 \%, \mathrm{~Pb}-6,96 \%$, As $1,69 \%, \mathrm{Sb}-1,99 \%)$ известны из материалов Торецкого селища в округе Биляра Болгарского улуса Золотой Орды первой половины $\mathrm{XV}$ в., изученных И.Е. Зайцевой [7, с. 136, табл. 1,261,262]. Также присутствие мышьяка $(\leq 1,3 \%)$ отмечено в зеркалах в выборке, изученной Л.Ф. Недашковским [18, с. 246].

Многокомпонентная бронза (CuSnPbZn, $50 \leq C u \leq 97,1 \leq P b \leq 48,1 \leq Z n \leq 30$, $1 \leq S n \leq 48, S n \geq Z n)$.

Три зеркала изготовлено из многокомпонентной бронзы. Два зеркала, происходящие из Селитренного (табл. 1,5) и Увекского (табл. 1,10 ) городищ, имеют относительно близкое соотношение основных легирующих компонентов в сплавах $(\mathrm{Cu}-79,2$ и $78,1 \%$, $\mathrm{Sn}-15,9$ и $11,9 \%, \mathrm{~Pb}-2,2$ и $8,1 \%, \mathrm{Zn}-1,6$ и 2,8 \%). Еще одно зеркало из Селитренного городища (табл. 1,4 ) отличается повышенным содержанием олова и относительно высоким содержанием цинка $(\mathrm{Cu}-56,9 \%, \mathrm{Sn}-32,6 \%$, $\mathrm{Pb}-4,3 \%, \mathrm{Zn}-5,6 \%)$. Сходный состав демонстрирует зеркало из материалов Болгарского городища [30, табл. III, 17]. Многокомпонентные бронзы наряду с оловянно-свинцовыми также достаточно широко представлены в материалах Болгарского городища и Торецкого селищ [4, с. $285 ; 30$, табл. II, 19,25,27,28]. Повышенным содержанием свинца выделяется также зеркало с Торецкого поселения $(\mathrm{Cu}-$ основа, $\mathrm{Sn}-7,37 \%, \mathrm{~Pb}-12,08 \%$, $\mathrm{Zn}-1,17 \%)$.

Обсуждение и выводы. В домонгольское время основным районом массового производства зеркал считаются аланские центры на Северном Кавказе [20, с. 237]. Предполагается существование производства зеркал для кочевников в древнерусских городах, прежде всего на городище Княжая гора (Чер- 
касская область, Украина), где обнаружены зеркала из оловянно-свинцовой бронзы, по своему художественному оформлению характерные для материальной культуры половцев и печенегов [12, с. 70-71]. На территорию Волжской Булгарии в XI-XII вв. предположительно поступают зеркала из Средней Азии, Приобья и Южной Сибири [23, с. 158]. Начиная со второй трети XIV в., когда происходит расцвет золотоордынской городской культуры и ремесла, они получают широкое распространение на территории Улуса Джучи, включая западные его регионы [9; 29], а с носителями данной культуры попадают и за его пределы. Практически все известные зеркала, найденные на территории древнерусских городов, связаны с контактами с кочевниками, прежде всего, выходцами из Золотой Орды [19, c. 148-149]. Химический анализ проведен для весьма небольшого количества из них и демонстрирует использование свинцово-оловянных сплавов с высоким содержанием олова (Устье 2 и 3, Серенск, Княжая гора). Кроме того, в слое второй половины ХІІІ в. Великого Новгорода было обнаружено зеркало китайского типа, изготовленное из халькопирита $\left(\mathrm{CuFeS}_{2}\right)$ с включениями олова, свинца и кремния, и аналогов такому составу на данный момент не обнаружено [19, с. 147-148]. Авторами публикации высказано осторожное предположение, что зеркало могло быть изготовлено как реплика с китайского оригинала в мастерских поволжских городских центров эпохи Золотой Орды, однако пока что результаты исследований как непосредственно золотоордынских зеркал, так и цветного металла в целом не дают возможности это подтвердить.

Зеркала на территории золотоордынских городов изготавливаются, прежде всего, в виде подражаний китайским и среднеазиатским зеркалам, отливаясь по методу оттиска. Для производства используются различные сплавы, прежде всего, оловянно-свинцовые бронзы с повышенным содержанием олова ( $\geq 20 \%)$. На данном уровне накопления материала можно отметить, что такой тип бронз на территории Золотой Орды концентрируется в округе Укека (рис. 2). Не зафиксировано ни одного зеркала, состав сплава которого можно было бы соотнести с китайскими бронзами. Другим широко используемым типом сплава являются многокомпонентные бронзы $(\mathrm{CuSnPbZn})$ с разными концентрациями основных элементов. Стандартно такой металл связывают с широко распространенной в средневековье практикой переплавки лома. В виде характерных для кочевников XIII-XIV вв. зеркал продолжает активно использоваться металл, несущий в себе такую архаичную черту, как мышьяк в составе.

Помимо достаточно типичных для изготовления зеркал сплавов в материалах Селитренного и Водянского городищ было зафиксировано использование оловянной бронзы с достаточно унифицированными концентрациями основных элементов и оловянной латуни. В выборках Болгарского улуса (Болгарское городище, Торецкое селище) зеркала с таким составом отсутствуют.

Полученные результаты должны пополнить базу данных по химическому составу средневекового металла Восточной Европы, а предварительные выводы способствовать более глубокому пониманию как особенностей металлообработки в Золотой Орде, так и культурных и экономических процессов, происходящих в Восточной Европе в эпоху Средневековья.

\section{ПРИМЕЧАНИЯ}

1 Исследование выполнено в рамках гранта Министерства науки и высшего образования Российской Федерации по теме «Домонгольские росписи Новгорода: археологический контекст и естественно-научные исследования (фрески Георгиевского собора Юрьева монастыря из раскопок 20132020 годов)», соглашение № 075-15-2021-576.

The research was carried out within the state assignment of Ministry of Science and Higher Education of the Russian Federation (theme «PreMongol frescoes in Novgorod: archaeological context and scientific research: The frescoes of St. George's Cathedral, Yuriev monastery from the 2013/2020 excavations»), agreement № 075-15-2021-576.

${ }^{2}$ Выражаю искреннюю благодарность за помощь в работе с коллекциями заведующему сектором археологии Саратовского областного музея краеведения К.Ю. Моржерину, научному сотруднику отдела археологических памятников Государственного исторического музея, кандидату исторических наук Е.М. Болдыревой, а также кандидату исторических наук И.А. Сапрыкиной (ИА РАН) за руководство и помощь в проведении анализов. 
${ }^{3}$ В настоящий момент составляют коллекцию Государственного исторического музея (шифры хранения: ГИМ 111012/оп. В 2694/3, ГИМ 114336/оп. В2698/29, ГИМ 109561/оп. В2739/11, ГИМ 111013/оп. В2695/14, ГИМ 111014/оп. В2696/32, ГИМ 111014/оп. В2696/33, ГИМ 111014/оп. В 2696/34, ГИМ 115084/оп. В 2763/30, ГИМ 115084/оп. В 2763/31).

${ }^{4}$ Составляют фонды Саратовского областного музея краеведения (шифры хранения: СМК НВСП 43865; АО 971, СМК НВСП 43868; АО 973, СМК
НВСП 43170/1-16; АО 1260, СМК НВ 45220/27-28, СМК НВСП 46338/17-20, СМК НВСП 4759/8).

${ }^{5}$ Выражаю благодарность сотрудникам отдела археологических исследований Государственного исторического музея за предоставленную возможность использования электронного микроскопа и РФА-спектрометра.

${ }^{6}$ Анализ выполнен младшим научным сотрудником Е.А. Сапрыкиным (Объединенный институг ядерных исследований, г. Дубна). 


\section{ПРИЛОЖЕНИЯ}

Таблица 1. Результаты анализа химического состава зеркал

Table 1. The results of the analysis of the chemical composition of the mirrors

\begin{tabular}{|c|c|c|c|c|c|c|c|c|c|c|c|c|c|c|}
\hline $\begin{array}{c}\text { № } \\
\text { п/п }\end{array}$ & $\begin{array}{c}\text { Место } \\
\text { и шифр } \\
\text { хранения }\end{array}$ & Памятник & $\begin{array}{l}\text { Место- } \\
\text { нахож- } \\
\text { дение }\end{array}$ & $\mathrm{Cu}$ & Sn & $\mathrm{Pb}$ & $\mathrm{Zn}$ & $\mathrm{Ag}$ & $\mathrm{Sb}$ & As & $\mathrm{Fe}$ & $\mathrm{Ni}$ & $\mathrm{Au}$ & $\mathrm{Hg}$ \\
\hline 1 & $\begin{array}{l}\text { ГИМ } \\
111012 / \text { оп. } \\
\text { В 2694/3 } \\
\end{array}$ & $\begin{array}{l}\text { Селит- } \\
\text { ренное - } \\
1986 \\
\end{array}$ & $\begin{array}{r}\text { XIII } \\
\text { п. } 15\end{array}$ & 74,7 & 7,3 & 0,0 & 17,7 & 0,0 & 0,0 & 0,0 & 0,3 & 0,0 & 0,0 & 0,0 \\
\hline 2 & $\begin{array}{l}\text { ГИМ } \\
\text { 114336/оп. } \\
\text { В 2698/29 }\end{array}$ & $\begin{array}{l}\text { Селит- } \\
\text { ренное - } \\
1990\end{array}$ & XVII & 76,4 & 15,9 & 4,4 & 0,0 & 0,1 & 0,2 & 0,0 & 2,5 & 0,0 & 0,0 & 0,1 \\
\hline 3 & $\begin{array}{l}\text { ГИМ } \\
\text { 109561/оп. } \\
\text { В 2739/11 }\end{array}$ & $\begin{array}{l}\text { Селит- } \\
\text { ренное }\end{array}$ & Пм & 93,1 & 0,8 & 2,4 & 0,0 & 0,2 & 0,1 & 3,2 & 0,2 & 0,1 & 0,0 & 0,0 \\
\hline 4 & $\begin{array}{l}\text { ГИМ } \\
\text { 111013/оп. } \\
\text { В 2695/14 }\end{array}$ & $\begin{array}{l}\text { Селит- } \\
\text { ренное - } \\
1987\end{array}$ & Пм & 56,9 & 32,6 & 4,3 & 5,6 & 0,1 & 0,1 & 0,1 & 0,1 & 0,0 & 0,0 & 0,1 \\
\hline 5 & $\begin{array}{l}\text { ГИМ } \\
111014 / \text { пा. } \\
\text { В 2696/32 }\end{array}$ & $\begin{array}{l}\text { Селит- } \\
\text { ренное - } \\
1988\end{array}$ & $\begin{array}{c}\text { XIII } \\
\text { пом. } 8\end{array}$ & 79,2 & 15,9 & 2,2 & 1,6 & 0,5 & 0,0 & 0,1 & 0,3 & 0,1 & 0,0 & 0,3 \\
\hline 6 & $\begin{array}{l}\text { ГИМ } \\
111014 / \text { пा. } \\
\text { В 2696/33 }\end{array}$ & $\begin{array}{l}\text { Селит- } \\
\text { ренное - } \\
1988\end{array}$ & $\begin{array}{l}\text { XIII } \\
3 / 56\end{array}$ & 76,1 & 23,0 & 0,1 & 0,2 & 0,2 & 0,1 & 0,2 & 0,2 & 0,0 & 0,0 & 0,0 \\
\hline 7 & $\begin{array}{l}\text { ГИМ } \\
111014 / \text { оп. } \\
\text { В 2696/34 }\end{array}$ & $\begin{array}{l}\text { Селит- } \\
\text { ренное - } \\
1988\end{array}$ & $\begin{array}{l}\text { XIII } \\
4 / 85\end{array}$ & 73,7 & 24,1 & 0,4 & 0,5 & 0,4 & 0,1 & 0,3 & 0,5 & 0,1 & 0,0 & 0,0 \\
\hline 8 & $\begin{array}{l}\text { ГИМ } \\
115084 / \text { оп. } \\
\text { В 2763/30 }\end{array}$ & $\begin{array}{l}\text { Водян- } \\
\text { ское - } \\
1974\end{array}$ & $\begin{array}{c}\text { II } \\
2 / 300\end{array}$ & 73,8 & 24,3 & 0,5 & 0,3 & 0,2 & 0,1 & 0,2 & 0,61 & 0,0 & 0,0 & 0,0 \\
\hline 9 & $\begin{array}{l}\text { ГИМ } \\
115084 / \text { пा. } \\
\text { В 2763/31 }\end{array}$ & $\begin{array}{l}\text { Водян- } \\
\text { ское - } \\
1974\end{array}$ & $\begin{array}{c}\text { II } \\
3 / 156\end{array}$ & 71,7 & 26,9 & 0,6 & 0,5 & 0,1 & 0 & 0,1 & 0,12 & 0,0 & 0,0 & 0,0 \\
\hline 10 & $\begin{array}{l}\text { СМК } \\
\text { НВСП } \\
43865 ; \\
\text { AO } 971\end{array}$ & $\begin{array}{l}\text { Увекское } \\
\text { городи- } \\
\text { ще - } 1911\end{array}$ & $\Pi_{M}$ & 78,2 & 12 & 8,2 & 2,8 & $\mathrm{X}$ & $\mathrm{X}$ & $\mathrm{X}$ & 0,67 & $\mathrm{X}$ & $\mathrm{X}$ & $\mathrm{X}$ \\
\hline 11 & $\begin{array}{l}\text { CMK } \\
\text { НВCП } \\
43868 ; \\
\text { AO 973 } \\
\end{array}$ & $\begin{array}{l}\text { Увекское } \\
\text { городи- } \\
\text { ще - } 1912\end{array}$ & Пм & 94,3 & 7,61 & 3,9 & $\mathrm{X}$ & $\mathrm{X}$ & $\mathrm{X}$ & $\mathrm{X}$ & 0,89 & $\mathrm{X}$ & $\mathrm{X}$ & $\mathrm{X}$ \\
\hline 12 & $\begin{array}{l}\text { СМК } \\
\text { НВCП } \\
43170 / 1-16 \\
\text { AO } 1260\end{array}$ & $\begin{array}{l}\text { Увекское } \\
\text { городи- } \\
\text { ще - } 1911\end{array}$ & Пм & 78,4 & 20,8 & 2,5 & $\mathrm{X}$ & $\mathrm{X}$ & $\mathrm{X}$ & $\mathrm{X}$ & $\mathrm{X}$ & $\mathrm{X}$ & $\mathrm{X}$ & $\mathrm{X}$ \\
\hline 13 & $\begin{array}{l}\text { CMK HB } \\
45220 / 27-28\end{array}$ & $\begin{array}{l}\text { Хмелев- } \\
\text { ское I се- } \\
\text { лище - } \\
2000 \\
\end{array}$ & $\Pi_{M}$ & 61,1 & 33 & 5,9 & $\mathrm{X}$ & $\mathrm{X}$ & $\mathrm{X}$ & $X$ & $\mathrm{X}$ & $\mathrm{X}$ & $X$ & $X$ \\
\hline 14 & $\begin{array}{l}\text { СМК } \\
\text { НВСП } \\
46338 / 17-20 \\
(\phi р-т ~ 1)\end{array}$ & $\begin{array}{l}\text { Хмелев- } \\
\text { ское I се- } \\
\text { лище - } \\
1998\end{array}$ & $\Pi_{M}$ & 80,7 & 23,4 & 6 & $\mathrm{X}$ & 0,9 & $\mathrm{X}$ & $\mathrm{X}$ & $\mathrm{X}$ & $\mathrm{X}$ & $X$ & $X$ \\
\hline 15 & $\begin{array}{l}\text { СМК } \\
\text { НВСП } \\
46338 / 17-20 \\
(\phi р-т ~ 2)\end{array}$ & $\begin{array}{l}\text { Хмелев- } \\
\text { ское I се- } \\
\text { лище - } \\
1998\end{array}$ & $\Pi_{M}$ & 65,9 & 27,4 & 8,9 & $X$ & $\mathrm{X}$ & $\mathrm{X}$ & $\mathrm{X}$ & $\mathrm{X}$ & $\mathrm{X}$ & $\mathrm{X}$ & $\mathrm{X}$ \\
\hline 16 & $\begin{array}{l}\text { СМК } \\
\text { НВСП } \\
4759 / 8 \\
\end{array}$ & $\begin{array}{l}\text { Широкий } \\
\text { Буерак - } \\
2002 \\
\end{array}$ & Пм & 53,3 & 44,4 & 2,3 & $\mathrm{X}$ & $\mathrm{X}$ & $\mathrm{X}$ & $\mathrm{X}$ & $\mathrm{X}$ & $\mathrm{X}$ & $\mathrm{X}$ & $\mathrm{X}$ \\
\hline
\end{tabular}




\section{АРХЕОЛОГИЯ ЕВРАЗИЙСКИХ СТЕПЕЙ}

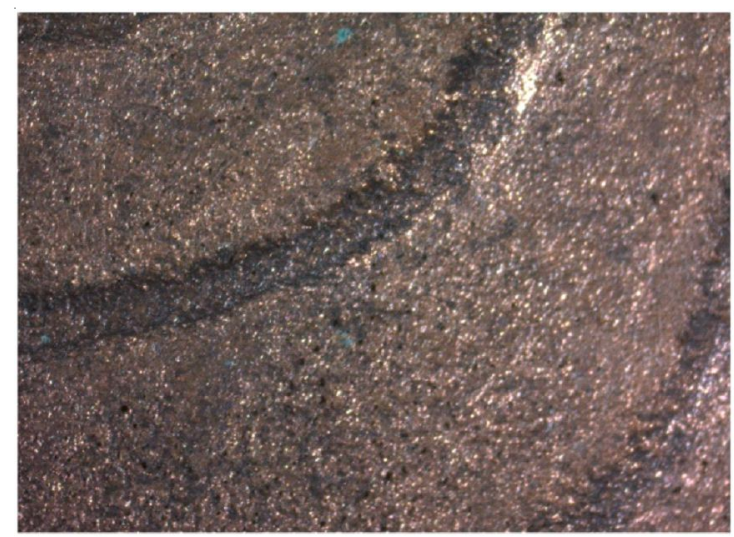

1

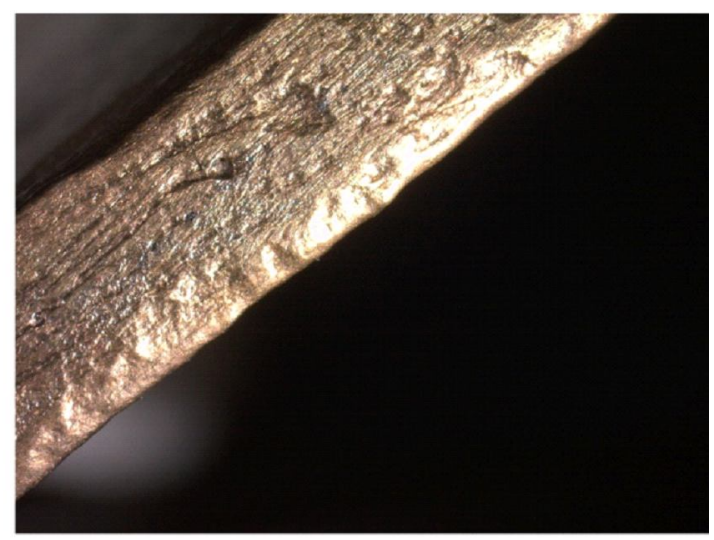

2

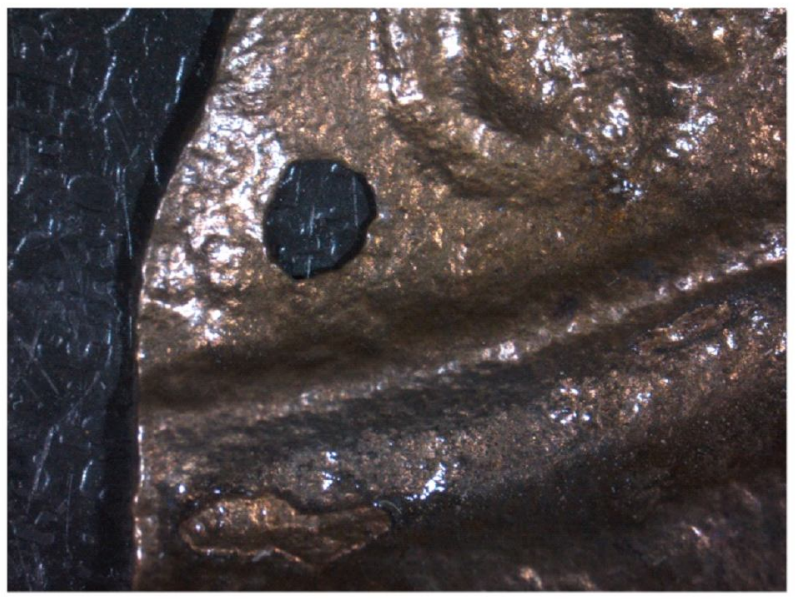

3

Рис. 1. Технологические следы на зеркалах:

1 - поверхность зеркала с четким рельефом; 2 - следы послелитейной обработки; 3 - пробитое отверстие

Fig. 1. Technological traces on the mirrors:

1 - surface with well-defined relief; 2 - traces of post-casting processing; 3 - punched hole 


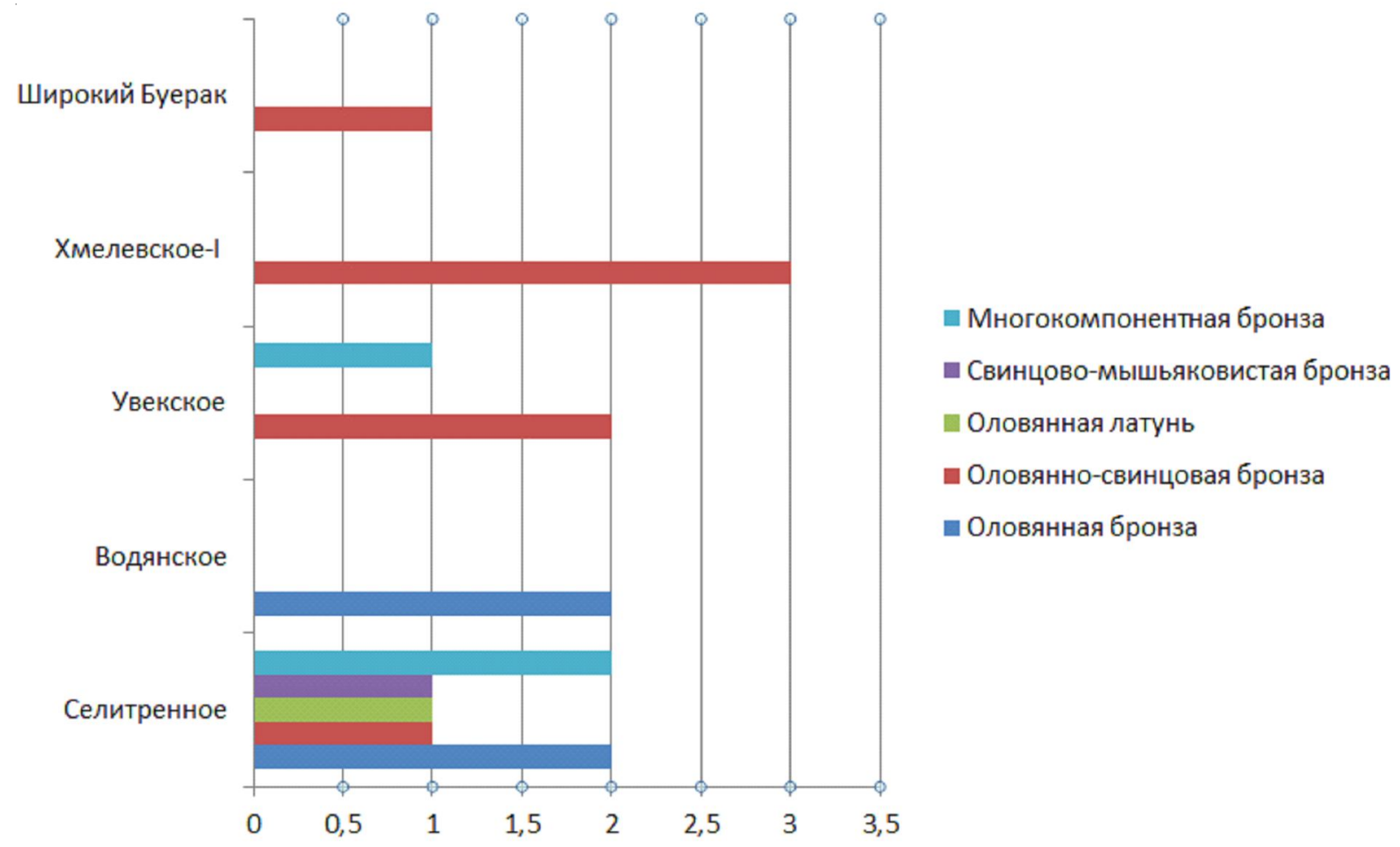

Рис. 2. Распределение типов сплавов по памятникам

Fig. 2. Distribution of alloy types by settlements 


\section{СПИСОК ЛИТЕРАТУРЫ}

1. Барцева, Т. Б. Цветная металлообработка скифского времени. Лесостепное днепровское левобережье / Т. Б. Барцева. - М. : Наука, 1981. - 127 с.

2. Богданова-Березовская, И. В. К вопросу о химическом составе зеркал Минусинской котловины / И. В. Богданова-Березовская // Лубо-Лесниченко Е. И. Привозные зеркала Минусинской котловины. К вопросу о внешних связях древнего населения Южной Сибири. - М. : Наука, 1975. - С. 131-149.

3. Валиулина, С. И. Балынгузское (Торецкое) III селище и проблема преемственности городской культуры в округе Билярского городища в золотоордынский период / С. И. Валиулина // Татарская археология. - 2004. - № 1-2. - С. 12-13.

4. Валиулина, С. И. К вопросу о цветной металлообработке Торецкого поселения XV века / С. И. Валиулина, И. Е. Зайцева // Диалог городской и степной культур на евразийском пространстве : материалы V Междунар. конф., посвящ. памяти Г.А. Федорова-Давыдова, 2-6 окт. 2011 г., Астрахань. - Казань : Ин-т археологии им. А.Х. Халикова АН РТ, 2011. - C.281-287.

5. Дегтярева, А. Д. Методика поверхностного изучения цветного металла / А. Д. Дегтярева // Вестник археологии, антропологии и этнографии. - 2006. - № 6. - С. 117-126.

6. Ениосова, Н. В. Химический состав ювелирного сырья эпохи средневековья и пути его поступления на территорию Древней Руси / Н. В. Ениосова, Р. А. Митоян, Т. Г. Сарачева // Цветные и драгоценных металлы и их сплавы на территории Восточной Европы в эпоху Средневековья. - М. : Вост. лит., 2008. - С. 107-188.

7. Зайцева, И. Е. Цветной металл Волжской Болгарии (предварительный анализ) / И. Е. Зайцева // Русь и Восток в IX-XVI веках: новые археологические исследования. - М. : Наука, 2010. - С. 116-138.

8. Зайцева, И. Е. Ювелирное дело «Земли вятичей» второй половины XI - XIII в. / И. Е. Зайцева, Т. Г. Сарачева. - М. : Индрик, 2011. - 404 с.

9. Золотоордынский погребальный комплекс с зеркалом с изображением сфинксов на Нижнем Днестре / М. В. Квитницкий, Н. П. Тельнов, С. Д. Лысенко, С. Н. Разумов, В. С. Синика // В поисках сущности : сб. ст. в честь 60-летия Н. Д. Руссева. - Кишинев : Stratum Plus, 2019. - С. 275-290.

10. Ковалева, К. С. Материалы к изучению изделий из цветных и драгоценных металлов Селитренного городища: химический состав / К. С. Ковалева // Вестник Волгоградского государственного университета. Серия 4, История. Регионоведение. Международные отношения. - 2020. - Т. 25, № 4. C. 328-347. - DOI: https://doi.org/10.15688/jvolsu4. 2020.4.22.
11. Ковалева, К. С. Результаты исследования химического состава металла и техники изготовления изделий из цветных металлов из раскопок курганных групп Бахтияровка и Царевского городища / К. С. Ковалева // Новые материалы и методы археологического исследования. От критики источника к обобщению и интерпретации данных : материалы V Междунар. конф. молодых ученых. - М. : ИА PAH, 2019. - C. 242-244. - DOI: https://doi.org/ 10.25681/IARAS.2019.978-5-94375-270-4.242-244.

12. Мезенцева, Г. Г. Древнеруське місто Родень : Княжа гора / Г. Г. Мезенцева. - Киів : Видавництво Київського університету, 1968. - 184 с.

13. Недашковский, Л. Ф. Золотоордынский город Укек и его округа / Л. Ф. Недашковский. - М. : Вост. лит., 2000. - 224 с.

14. Недашковский, Л. Ф. Материалы с селища Широкий Буерак / Л. Ф. Недашковский, М. Б. Шигапов // Археология Евразийских степей. - 2018. № 4. - С. 149-153.

15. Недашковский, Л. Ф. Средневековые металлические зеркала с Увекского городища / Л. Ф. Недашковский, А. И. Ракушин // Татарская археология. -1998 . - № 1 (2). - С. 32-51.

16. Недашковский, Л. Ф. Украшения и зеркала с Хмелевского I селища / Л. Ф. Недашковский, М. Б. Шигапов // Ученые записки Казанского университета. Серия: Гуманитарные науки. - 2015. Т. 157, кн. 3. - С. 34- 45.

17. Недашковский, Л. Ф. Химический состав изделий из цветных металлов с золотоордынских поселений центральной части Саратовской области / Л. Ф. Недашковский // Нижневолжский археологический вестник. - Вып. 5. - Волгоград : Изд-во ВолГУ, 2002.- С. 335-347.

18. Недашковский, Л. Ф. Химический состав изделий из цветных металлов с золотоордынских поселений северных районов Нижнего Поволжья / Л. Ф. Недашковский // Stratum Plus. - 2018. - № 6. С. 243-254.

19. Олейников, О. М. Металлическое зеркало китайского типа из Великого Новгорода / О. М. Олейников, К. А. Руденко // Российская археология. 2018. - № 3. - С. 141-152.

20. Полякова, Г. Ф. Изделия из цветных и драгоценных металлов / Г. Ф. Полякова // Город Болгар: ремесло металлургов, кузнецов, литейщиков. Казань : ИЯЛИ АН Татарстана, 1996. - С. 154-268.

21. Равич, И. Г. Особенности состава и технология изготовления миниатюрных сарматских зеркал из «белой бронзы» / И. Г. Равич // Российская археология. - 1995. - № 3. - С. 157-164.

22. Руденко, К. А. Металлические зеркала золотоордынского времени из собрания Национального музея Республики Татарстан / К. А. Руденко // Татарская археология. - 2004. - № 1-2 (12-13). -С. 111-156. 
23. Руденко, К. А. Металлические зеркала из Волжской Булгарии и их сибирские параллели / К. А. Руденко // Древности Сибири и Центральной Азии. - Горно-Алтайск : Изд-во ГАГУ, 2013. № 5 (17). - С. 150-160.

24. Сапрыкина, И. А. Цинкосодержащие сплавы в цветной металлообработке лесной и лесостепной зоны конца I тыс. до н. э. - первой половины I тыс. н. э.: «индекс романизации» / И. А. Сапрыкина // Земли родной минувшая судьба... : сб. ст. к юбилею А. Е. Леонтьева. - М. : ИА РАН, 2018. C. 277-287.

25. Тишкин, А. А. Металлические зеркала как источник по древней и средневековой истории Алтая (по материалам музея археологии и этнографии Алтая Алтайского государственного университета) / А. А. Тишкин, Н. Н. Серегин. - Барнаул : Азбука, 2011.-144 с.

26. Тишкин, А. А. Результаты комплексного изучения металлических зеркал из средневековых памятников Алтая и Южной части Верхнего Приобья / А. А. Тишкин, Н. Н. Серегин // Вестник Томского государственного университета. - 2018. № 434. - C. 129-136. - DOI: https://doi.org/10.17223/ $15617793 / 434 / 17$.

27. Федоров-Давыдов, Г. А. Кочевники Восточной Европы под властью золотоордынских ханов. Археологические памятники / Г. А. Федоров-Давыдов. - М. : Изд-во МГУ, 1966. -276 с.

28. Федоров-Давыдов, Г. А. Золотоордынские города Поволжья / Г. А. Федоров-Давыдов. - М. : Изд-во Моск. ун-та, 1994. - 232 с.

29. Фидельский, С. А. Бронзовое зеркало золотоордынского времени из окрестностей села Тея на левобережье Нижнего Днестра / С. А. Фидельский, М. М. Чореф // В поисках сущности : сб. ст. в честь 60-летия Н. Д. Руссева. - Кишинев : Stratum Plus, 2019. - C. 263-274.

30. Хлебникова, Т. А. Анализы Болгарского цветного металла / Т. А. Хлебникова // Город Болгар: ремесло металлургов, кузнецов, литейщиков. Казань : ИЯЛИ АН Татарстана, 1996. - С. 258-279.

31. Яворская, Л. В. Город в степи: некрополи округи Царевского городища как источник для реконструкции исторических процессов / Л. В. Яворская // Археология Нижнего Поволжья на рубеже тысячелетий : материалы Всерос. науч.-практ. конф. Астрахань : Изд-во Астрахан. гос. пед. ун-та, 2001. C. $83-87$.

\section{REFERENCES}

1. Bartseva T.B. Tsvetnaya metalloobrabotka skifskogo vremeni. Lesostepnoe dneprovskoe levoberezh'e [Non-Ferrous Metalworking of the
Scythian Time. Forest-Steppe Dnieper Left Bank]. Moscow, Nauka Publ., 1981. 127 p.

2. Bogdanova-Berezovskaya I.V. K voprosu o khemicheskom sostave zerkal Minusinskoy kotloviny [Discussing Chemical Composition of Mirrors from Minusinsk Hollow]. Lubo-Lesnichenko E.I. Privoznye zerkala Minusinskoy kotloviny. K voprosu o vneshnih svyazyah drevnego naseleniya Yuzhnoy Sibiri [LuboLesnichenko E.I. Imported Mirrors of Minusinsk Hollow. Discussing External Relations of Ancient Population of South Siberia]. Moscow, Nauka Publ., 1975, pp. 131-149.

3. Valiulina S.I. Balynguzskoe (Toretskoe) III selishche i problema preemstvennosti gorodskoy kul'tury v okruge Bilyarskogo gorodishcha $\mathrm{v}$ zolotoordynskiy period [The Balynguz (Toretsk) $3^{\text {rd }}$ Settlement and the Problem of the Continuity of Urban Culture in the District of Bilyar Settlement in the Golden Horde Period]. Tararskaya arkheologiya, 2004, no. 1-2, pp. 12-13.

4. Valiulina S.I., Zaytseva I.E. K voprosu o tsvetnoy metalloobrabotke Toretskogo poseleniya XV veka [Discussing Non-Ferrous Metallurgy of Toretskoe Settlement of the $15^{\text {th }}$ Century]. Dialog gorodskoy i stepnoy kul'tur na evraziyskom prostranstve: materialy $V$ Mezhdunar. konf., posvyashh. pamyati G.A. Fedorova-Davydova, 26 okt. 2011 g., Astrakhan [Dialogue of the Urban and Steppe Cultures in the Eurasian Space. Proceedings of the $5^{\text {th }}$ International Conference Dedicated to the Memory of G.A. Fedorov-Davydov, October 2-6, 2011, Astrakhan]. Kazan, Institut arkheologii im. A.Kh. Khalikova AN RT, 2011, pp. 281-287.

5. Degtiareva A.D. Metodika poverhnostnogo izucheniya tsvetnogo metalla [Method of Surface Study of Non-Ferrous Metal]. Vestnik arkheologii, antropologii i etnografii, 2006, no. 6, pp. 117-126.

6. Eniosova N.V., Mitoyan R.A., Saracheva T.G. Himicheskiy sostav yuvelirnogo syr'ya epohi srednevekov'ya i puti ego postupleniya na territoriyu Drevney Rusi [The Chemical Composition of Jewelry Raw Materials from the Middle Ages and Its Entry into the Territory of Ancient Russia]. Tsvetnye $i$ dragotsennyh metally $i$ ih splavy na territorii Vostochnoy Evropy v epohu Srednevekov'ya [NonFerrous and Precious Metals and Their Alloys in Eastern Europe in the Middle Ages]. Moscow, Vostochnaya literatura Publ., 2008, pp. 107-188.

7. Zaytseva I.E. Tsvetnoy metall Volzhskoy Bolgarii (predvaritel'nyy analiz) [Non-ferrous Metal of Volga Bulgaria (Preliminary Analysis)]. Rus' $i$ Vostok v IXXVI vekah: novye arheologicheskie issledovaniya [Rus' and the East in the $9^{\text {th }}-16^{\text {th }}$ Centuries: NewArchaeological Research]. Moscow, Nauka Publ., 2010, pp. 116-138.

8. Zaitseva I.E., Saracheva T.G. Yuvelirnoe delo «Zemli viatichey» vtoroy poloviny XI-XIII v. [Jeweler's 
Craft of "Land of Viatichi" in the Second Half of the $11^{\text {th }}-13^{\text {th }}$ Centuries]. Moscow, Indrik Publ., 2011. 404 p.

9. Kvitnytskyi M.V., Telnov N.P., Lysenko S.D., Razumov S.N., Sinika V.S. Zolotoordynskiy pogrebal'nyy kompleks s zerkalom s izobrazheniem sfinksov na Nizhnem Dnestre [Golden Horde Grave with a Mirror with the Image of Sphinxes in the Lower Dniester Region]. Vpoiskah suschnosti: sb. st. v chest' 60-letiya N.D. Russeva [In Search of the Essence. Collection of Articles in Honour of Nicolai Russev on the Occasion of His $60^{\text {th }}$ Birthday]. Kishinev, Stratum Plus Publ., 2019, pp. 275-290.

10. Kovaleva K.S. Materialy k izucheniyu izdeliy iz tsvetnyh i dragotsennyh metallov Selitrennogo gorodischa: khimicheskiy sostav [Materials for the Study of Items from Non-Ferrous and Precious Metals of Selitrennoe Settlement: Chemical Composition]. Vestnik Volgogradskogo gosudarstvennogo universiteta. Seriya 4. Istoriya. Regionovedenie. Mezhdunarodnye otnosheniya [Science Journal of Volgograd State University. History. Area Studies. International Relations], 2020, vol. 25, no. 4, pp. 328347. DOI: https://doi.org/10.15688/jvolsu4.2020.4.22.

11. Kovaleva K.S. Rezul'taty issledovaniya himicheskogo sostava metalla i tekhniki izgotovleniya izdeliy iz tsvetnyh metallov iz raskopok kurgannyh grupp Bahtiyarovka i Tsarevskogo gorodishcha [The Results of the Study of the Chemical Composition of Metal and the Manufacture of Non-Ferrous Metal Products from the Excavations of the Kurgan Groups of Bakhtiyarovka and Tsarevskoe Settlement]. Novye materialy i metody arheologicheskogo issledovaniya. Ot kritiki istochnika $k$ obobshcheniya $i$ interpretatsii dannyh: materialy V Mezhdunar. konf. molodyh uchenyh [New Materials and Methods of Archaeological Research. From Criticism of the Source to Generalization and Interpretation of Data. Proceedings of the $5^{\text {th }}$ International Conference of Young Scientists]. Moscow, IARAN, 2019, pp. 242-244. DOI: 10.25681/IARAS.2019.978-5-94375-270-4.242-244.

12. Mezentseva G.G. Drevnerus'ke misto Roden': Knyazha gora [The Ancient Russian City Roden: Knyazha Mountain]. Kiev, Vydavnytstvo Kyyivs'koho universytetu, 1968. $184 \mathrm{p}$.

13. Nedashkovskiy L.F. Zolotoordynskiy gorod Ukek i ego okruga [The Golden Horde City Ukek and Its Neighborhood]. Moscow, Vostochnaya Literatura Publ., 2000. 224 p.

14. Nedashkovsky L.F., Shigapov M.B. Materialy s selischa Shirokiy Buerak [Materials from the Shiroky Buerak Settlement]. Arkheologiya Evraziyskih stepey [Archaeology of the Eurasian Steppes], 2018, no. 4, pp. 149-153.

15. Nedashkovsky L.F., Rakushin A.I. Srednevekovye metallicheskie zerkala s Uvekskogo gorodischa [Medieval Metal Mirrors from Uvek
Settlement]. Tatarskaya arkheologiya, 1998, no. 1 (2), pp. 32-51.

16. Nedashkovsky L.F., Shigapov M.B. Ukrasheniya i zerkala $\mathrm{s}$ Khmelevskogo I selischa [Wearing-Apparel Components and Mirrors from the Hmelevskoe I Settlement]. Uchenye Zapiski Kazanskogo Universiteta. Seriya: Gumanitarnye nauki, 2015, vol. 157, book 3, pp. 34-45.

17. Nedashkovsky L.F. Himicheskiy sostav izdeliy iz tsvetnyh metallov s zolotoordynskih poseleniy tsentral'noy chasti Saratovskoy oblasti [Chemical Composition of Non-Ferrous Articles from the Golden Horde Settlements of the Central Part of Saratov Region]. Nizhnevolzhskiy arheologicheskiy vestnik [The Lower Volga Archaeological Bulletin]. Volgograd, Izd-vo VolGU, 2002, iss. 5, pp. 335-347.

18. Nedashkovsky L.F. Himicheskiy sostav izdeliy iz tsvetnyh metallov s zolotoordynskih poseleniy severnyh rayonov Nizhnego Povolzh'ya [Chemical Composition of Non-ferrous Artifacts from the Golden Horde Settlements of the Northern Areas of the Lower Volga Region]. Stratum Plus, 2018, no. 6, pp. 243-254.

19. Oleynikov O.M., Rudenko K.A. Metallicheskoe zerkalo kitayskogo tipa iz Velikogo Novgoroda [Metal Mirror of Chinese Type from Velikiy Novgorod]. Rossiyskaya arheologiya [Russian Archaeology], 2018, no. 3, pp. 141-152.

20. Polyakova G.F. Izdeliya iz tsvetnyh i dragotsennyh metallov [Non-Ferrous and Precious Metal Items]. Gorod Bolgar: remeslo metallurgov, kuznetsov, liteyshchikov [City of Bolgar: Craft of Metallurgists, Blacksmiths, Casters]. Kazan, IYaLI AN Tatarstana, 1996, pp. 154-268.

21. Ravitch I.G. Osobennosti sostava i tekhnologiya izgotovleniya miniaturnykh samatskih zerkal iz «beloy bronzy» [Peculiarities of the Compound and Making Technology of the Tiny Sarmatian Mirrors Made of the "White Bronze"]. Rossiyskaya arkheologiya [Russian Archaeology], 1995, no. 3, pp. 157-164.

22. Rudenko K.A. Metallicheskie zerkala zolotoordynskogo vremeni iz sobraniya Natsional'nogo muzeya Respubliki Tatarstan [The Golden Horde Time Metal Mirrors from Collection of the National Museum of Tatarstan Republic]. Tatarskaya arkheologiya, 2004, no. 1-2(12-13), pp. 111-156.

23. Rudenko K.A. Metallicheskie zerkala iz Volzhskoy Bulgarii i ih sibirskie paralleli [Metal Mirrors from Volga Bulgaria and Its Siberian Parralels]. Drevnosti Sibiri $i$ Tsentral'noy Azii [Antiquates of Siberia and Central Asia]. Gorno-Altaysk, Izd-vo GAGU, 2013, no. 5(17), pp. 150-160.

24. Saprykina I.A. Tsinkosoderzhaschie splavy $\mathrm{v}$ tsvetnoy metalloobrabotke lesnoy i lesostepnoy zony kontsa I tys. do n.e. - pervoy poloviny I tys. 
n.e.: «indeks romanizatsii» [Zinc-Containing Alloys in Non-Ferrous Metalworking of the Forest and ForestSteppe Zone at the End of the $1^{\text {st }}$ Millennium BC - The First Half of the $1^{\text {st }}$ Millennium AD: "Romanization Index"]. Zemli rodnoy minuvshaya sud'ba...: sb. st. $k$ yubileyu A.E. Leont'eva [Past Fate of Motherland... Collection of Articles to the Anniversary of A.E. Leontiev]. Moscow, IA RAN, 2018, pp. 277-287.

25. Tishkin A.A., Seregin N.N. Metallicheskie zerkala kak istochnik po drevney $i$ srednevekovoy istorii Altaya (po materialam muzeya arheologii $i$ etnografii Altaya Altayskogo gosudarstvennogo universiteta) [Metal Mirrors As a Source on the Ancient and Medieval History of Altai (Based on Materials from the Museum of Archeology and Ethnography of Altai, Altai State University)]. Barnaul, Azbuka Publ., 2011. 144 p.

26. Tishkin A.A., Seregin N.N. Rezul'taty kompleksnogo izucheniya metallicheskih zerkal iz srednevekovyh pamyatnikov Altaya i Yuzhnoy chasti Verkhnego Priob'ya [Results of a Comprehensive Study of Metal Mirrors from the Medieval Sites of the Altai and the Southern Part of the Upper Ob Region]. Vestnik Tomskogo gosudarstvennogo universiteta [Tomsk State University Journal], 2018, no. 434, pp. 129-136. DOI: https://doi.org/10.17223/15617793/434/17.

27. Fedorov-Davydov G.A. Kochevniki Vostochnoy Evropy pod vlast'yu zolotoordynskih khanov. Arkheologicheskie pamyatniki [Nomads of Eastern Europe Under the Dominion of Golden Horde Khans. Archaeology Monuments]. Moscow, Izd-vo MGU, 1966.276p.
28. Fedorov-Davydov G.A. Zolotoordynskie goroda Povolzh'ya [The Golden Horde Cities of the Volga Region]. Moscow, Izd-vo Moskovskogo universiteta, 1994. 232 p.

29. Fidelski S.A., Choref M.M. Bronzovoe zerkalo zolotoordynskogo vremeni iz okrestnostey sela Teya na levoberezh'e Nizhnego Dnesrta [A Bronze Mirror of the Golden Horde Time from the Outskirts of the Teia Village on the Left Bank of the Lower Dniester]. V poiskah suschnosti: sb. st. v chest' 60-letiya N.D. Russeva [In Search of the Essence. Essays in Honour of Nicolai Russev on the Occasion of His $60^{\text {th }}$ Birthday]. Kishinev, Stratum Plus, 2019, pp. 263-274.

30. Hlebnikova T.A. Analizy Bolgarskogo tsvetnogo metalla [Analyzes of Bulgarian Non-Ferrous Metal]. Gorod Bolgar: remeslo metallurgov, kuznetsov, liteyshchikov [City of Bolgar: Craft of Metallurgists, Blacksmiths, Casters]. Kazan, IYaLI AN Tatarstana, 1996, pp. 258-279.

31. Yavorskaya L.V. Gorod v Stepi: nekropoli okrugi Tsarevskogo gorodischa kak istochnik dlya reconstruktsii istoricheskih protsessov [City in the Steppe: Necropolises in the Region of Tsarevskoe Settlement As the Source for the Reconstruction of Historical Processes]. Arheologiya Nizhnego Povolzh'ya na rubezhe tysyacheletiy: materialy Vseros. nauch.-prakt. konf. [Archaeology of the Lower Volga Region at the Turn of the Millennium. Proceedings of the All-Russian Scientific and Practical Conference]. Astrakhan, Izd-vo Asrakhanskogo gosudarstvennogo pedagogicheskogo universiteta, 2001, pp. 83-87.

\section{Information About the Author}

Kseniya S. Kovaleva, Researcher, Laboratory for Architectural Archaeology and Interdisciplinary Studies of Monuments of Architecture, Institute of Archaeology, RAS, Dm. Ulyanova St, 19, 117036 Moscow, Russian Federation; Laboratory Assistant, Laboratory for Archaeological Research, Volgograd State University, Prosp. Universitetsky, 100, 400062 Volgograd, Russian Federation, ksenmorgan@gmail.com, kovaleva@volsu.ru,https://orcid.org/0000-0002-5429-1072

\section{Информация об авторе}

Ксения Сергеевна Ковалева, научный сотрудник лаборатории архитектурной археологии и междисциплинарного изучения архитектурных памятников, Институт археологии РАН, ул. Дм. Ульянова, 19, 117036 г. Москва, Российская Федерация; лаборант лаборатории археологических исследований, Волгоградский государственный университет, просп. Университетский, 100, 400062 г. Волгоград, Российская Федерация, ksenmorgan@gmail.com, kovaleva@volsu.ru, https://orcid.org/0000-0002-5429-1072 